\title{
Exploring the patterns and causes of land use changes in south-west Sweden
}

\author{
Rixt de Jong $\cdot$ Per Lagerås
}

Received: 19 February 2010/Accepted: 7 August 2010/Published online: 5 October 2010

(C) Springer-Verlag 2010

\begin{abstract}
To study the causes of agricultural declines in south-west Sweden, a multi-proxy study including pollen analysis, bog surface wetness indicators and aeolian sediment influx reconstructions was carried out on the Store Mosse Bog, situated on the coastal plain of Halland. Patterns of agricultural changes during the past 6,000 years from this study were compared to one additional site on the coastal plain (Undarsmosse Bog) and to four sites in the forested upland region. First, we compared land use activity on the coastal plain and in upland regions of south-west Sweden. Three periods with reduced agricultural activities were observed, primarily in records from the coastal plain. Next, the causes for these declines were studied by comparing land use indicators in the pollen records from the Store Mosse and Undarsmosse peat bogs to independent climatic reconstructions based on the same core material (past storm activity based on aeolian sediment influx onto the peat bogs; bog surface wetness reconstructed from organic bulk density measurements). Since the climatic reconstructions and pollen analysis were carried out on the same peat cores, a
\end{abstract}

Communicated by M.J. Gaillard.

R. de Jong $(\bowtie)$

Department of Earth and Ecosystem Sciences, Lund University, 22362 Lund, Sweden

e-mail: dejong@giub.unibe.ch

P. Lagerås

Swedish National Heritage Board, UV Syd, Odlarevägen 5,

22660 Lund, Sweden

Present Address:

R. de Jong

Oeschger Centre for Climate Change Research and Institute

of Geography, University of Bern, Erlachstrasse 9a,

3012 Bern, Switzerland direct comparison between the timing of climatic events and land use changes was possible. Results indicate that climatic perturbations prior to ca. 1,000 years ago contributed to or possibly caused agricultural declines. The agricultural expansions near the Store Mosse and Undarsmosse bogs from 3000 to $2600 \mathrm{cal}$. yrs B.P. ended at the time when climatic proxy indicators recorded climatic instability (from ca 2600 to 2200 cal. yrs B.P.). The same sequence of events was recorded around $1500 \mathrm{cal}$. yrs B.P. and from 1200 to $1000 \mathrm{cal}$. yrs в.P., suggesting a climatic cause for these agricultural declines as well. The well-known climatic perturbations associated with the Little Ice Age, however, did not have a visible impact on agricultural activities. By this time, advances in land use knowledge and technology may have drastically diminished society's sensitivity to climatic changes.

Keywords Climate variability - South-west Sweden . Agriculture - Aeolian sediment influx - Bog surface wetness

\section{Introduction}

Both climatic change and human impact have affected the Holocene vegetation history of north-west Europe. For this region, a pattern of apparently parallel and similar changes in land use intensity was observed (Berglund 2003). These changes were tentatively linked to climatic events recorded in the North Atlantic region, suggesting a causal link between climate and land use changes (Berglund 2003). In a similar study, Gajewski et al. (2006) found seemingly simultaneous phases of vegetation change across Europe and North America and also linked these to climatic changes. According to Tinner et al. (2003), who compared 
land use and climatic changes in the Alpine region from 2300 B.C. to A.D. 800, increases in precipitation were important drivers of crop failure. Prehistoric and medieval agriculture in Europe depended heavily on drought-adapted cereals from the Near East that, under humid conditions, were sensitive to parasite attacks (Tinner et al. 2003). Therefore, humid conditions during the growing season could severely endanger crop yields. The extent to which climatic factors control land use is, however, still strongly debated (Berglund 2003). In addition, Messerli et al. (2000) pointed out that the degree of climatic impact is also dependent on the vulnerability of a society, which may change through time.

To test the possible causal link between climatic changes and land use, chronological uncertainties between reconstructed vegetation changes and climatic reconstructions should be minimal. In this study, we compared reconstructed land use activities near the Store Mosse Bog site with independent climatic proxies derived from the same sediment core, thus ensuring chronological consistency between both records. We used organic bulk density (OBD) measurements, a measure for the degree of decomposition of the peat, together with aeolian sediment influx, a proxy reflecting atmospheric circulation vigour. OBD values record local variations in bog surface wetness, which are controlled by within-bog processes as well as regional-scale climatic processes (see discussion in de Jong et al. 2009). Aeolian sediment influx (ASI) reflects the number of sand grains transported to the centre of the study sites by wind action (Björck and Clemmensen 2004). ASI values were shown to reflect regional-scale processes (e.g. de Jong et al. 2007, 2009), and were interpreted as a proxy for 'storminess' (storm frequency and/or intensity). Similar data were available from the nearby Undarsmosse Bog site (de Jong et al. 2006). Both records cover ca. 6,000 years of vegetation history and climatic fluctuations.

Although much is known about vegetation and land use changes in southern Sweden (e.g. the 'Ystad Project', Berglund et al. 1991), the coastal zone of Halland is relatively poorly known in this respect. Digerfeldt (1982) and Digerfeldt and Håkansson (1993) described the Holocene regional vegetation history of Halland and the palaeolimnology (eutrophication) of nearby Lake Sämbosjön, based on pollen, diatom and chemical analyses of the lake sediments. According to this study, human activity became an important driver of the landscape, vegetation-and limnological changes from ca. 6000 cal. yrs B.P., i.e. the time of the introduction of agriculture in southern Sweden, but especially from $3200 \mathrm{cal}$. yrs B.P. onwards. The particularly intense human activity in the area from 3200 cal. yrs B.P. (Bronze Age) was also recognised in the archaeological record (Digerfeldt and Welinder 1985). In this study, we first present the pollen record from the Store Mosse peat bog, a large bog situated on the coastal plain of Halland, south-west Sweden (Fig. 1). To study possible regional patterns of land use changes, we compared the timing of the development of agriculture during the past 6,000 years in detail at six sites. Two of these sites are located on the coastal plain, Store Mosse Bog (this study) and Undarsmosse Bog (de Jong et al. 2006), while the other four sites are in the upland regions of south-west Sweden (Östra Ringarp, Grisavad, Bjärabygget, Värsjö Utmark; Lagerås 2007). These results were compared to additional vegetation reconstructions from the same region (Fig. 1). Finally, to decipher the possibly causes for agricultural declines, independently derived climatic reconstructions from the two lowland sites were compared to reconstructed land use changes from the same cores.

\section{Study area}

\section{Modern vegetation}

The province of Halland lies at the boundary of two plantgeographical zones; the nemoral forest region in the western part, and the boreo-nemoral zone in the eastern part (according to Sjörs 1965). The remaining forests in the relatively open landscape of the nemoral zone are dominated by deciduous forest trees, whereas forests in the boreo-nemoral region are mixed deciduous-coniferous, with a dominance of coniferous trees. Currently, the northern limit of Fagus sylvatica lies in Halland, as does the southern limit of Picea abies (Björkman and Bradshaw 1996). Due to large-scale Picea and Pinus plantations, coniferous trees are currently common in the entire region. The geological contrast between the coastal plain, with thick till deposits of silt and sand, and the glacial tills in the east (often with the underlying acidic bedrock exposed), explains the distinct difference between the types of vegetation in each area and the possibilities for agriculture. The coastal plain is currently dominated by agriculture, mainly crop cultivation. On elevated ground Picea plantations are common, whereas in the northern part of Halland Calluna heaths are found along the coast. Further inland, deciduous forests with beech trees occur, as well as Picea and Pinus plantations. Although agriculture is also practiced in the upland regions, at present the uplands are densely forested and agriculture is more widespread in the coastal area.

\section{Climate regime}

The regional climate in the province of Halland is strongly controlled by westerly air flow, resulting in mild maritime conditions with relatively cool summers $\left(16^{\circ} \mathrm{C}\right.$ July average temperature) and mild winters $\left(-2^{\circ} \mathrm{C}\right.$ January average 
Fig. 1 Map showing the position of study sites mentioned in the text and used in Fig. 3: 1 Store Mosse Bog (this study), 2 Undarsmosse Bog (de Jong et al. 2007), 3 Östra

Ringarp, 4 Bjärabygget, 5 Värsjö Utmark and 6 Grisavad (all in Lagerås 2007). In addition the locations of Lake Sämbosjön (7 Digerfeldt 1982), Svartemosse ( 8 Gustavsson et al. 2009), Yttra Berg (9 Sköld et al. 2010) and the Biskopstorp forest reserve (10 Lindbladh et al. 2008) are indicated. Also shown are detailed maps of the Store Mosse bog and the coring point

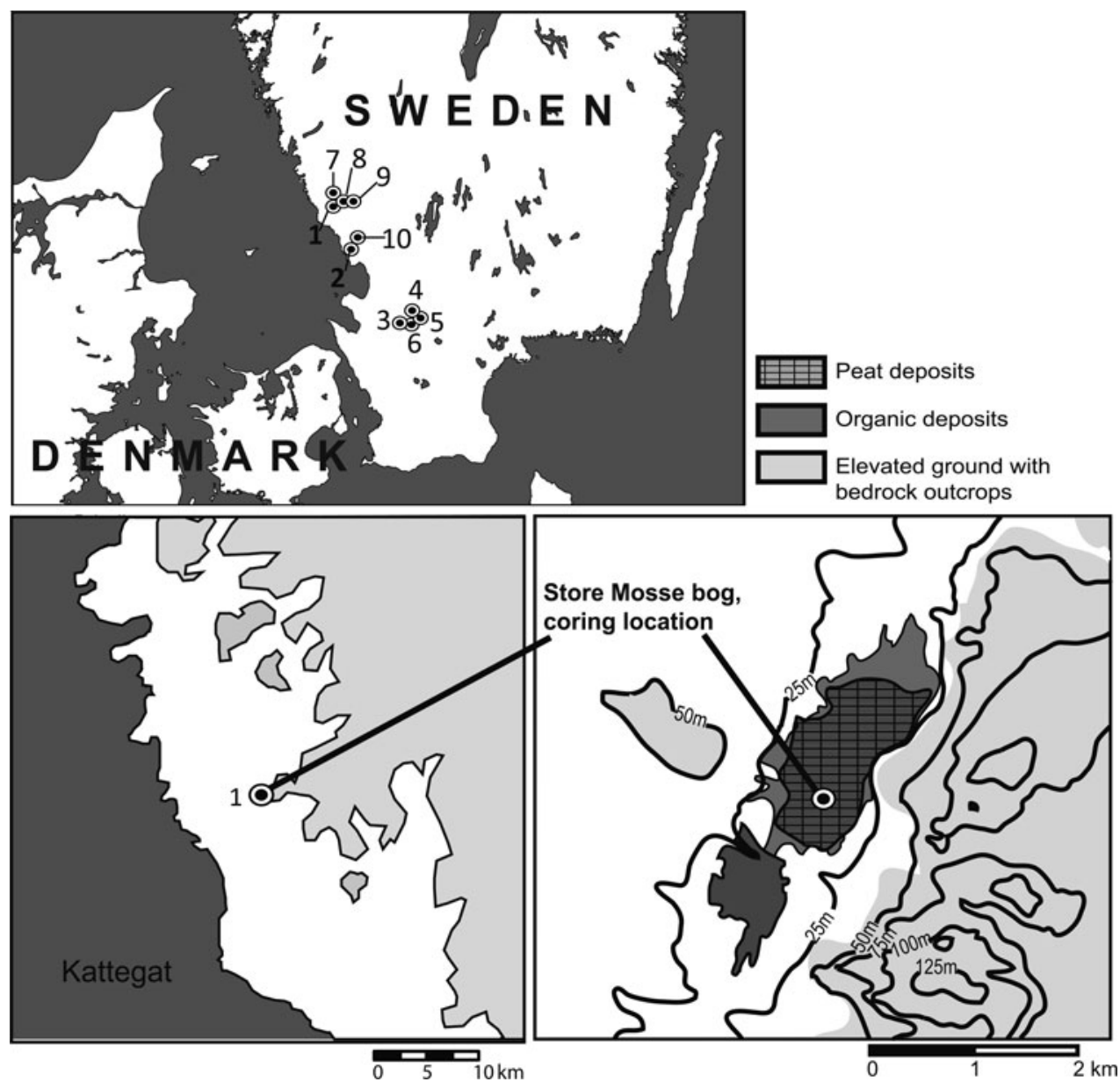

temperature). Precipitation in Halland is relatively low in the narrow coastal zone, on average $700-800 \mathrm{~mm}$ per year, whereas values up to $1,200 \mathrm{~mm}$ per year are recorded in the upland region (SMHI 2010, all data are average values for the time period A.D. 1961-1990). The number of days with snow cover per year varies from 25 to 75 days. The weather in all seasons is variable, being controlled by the strength, position and frequency of passing cyclones (Jönsson 1994). Storms can be severe in this area, and are most common and violent in the winter season. Although they have a predominantly westerly direction, easterly winds of storm force also occur (Alexandersson et al. 1998; Nilsson et al. 2004). Easterly winds are related to the presence of a high-pressure field over northern Scandinavia, which diverts westerlies to a more southerly position ('blocking situation', Jönsson and Bärring 1994). In winter this brings cold and dry northeastern air masses into the study area.

\section{Coastal plain sites}

The Store Mosse and Undarmosse bogs are situated on the low-lying coastal plain of the province of Halland, southwest Sweden (Fig. 1). The coastal plain is ca. 10-20 km wide and the elevation is $10-25 \mathrm{~m}$ a.s.l. The deglaciation of the coastal plain took place around 16000 cal. yrs B.P. (Lundqvist and Wohlfarth 2001). However, after initial deglaciation the ice margin fluctuated strongly. This resulted in the formation of a series of moraine ridges and thick glaciofluvial and glaciomarine deposits west of the ice margin (Berglund 1995). Substantial fluctuations of relative sea level after deglaciation caused considerable reworking of sediments below the marine limit (situated at ca 65-75 $\mathrm{m}$ a.s.1.; Berglund 1995). The coastal plain is characterised by silty and sandy wave-reworked glacial sediments, in part overlain by dune fields and peat deposits. Granitic bedrock outcrops reach a maximum elevation of $140 \mathrm{~m}$ a.s.1.

The Store Mosse Bog lies at the transition from the coastal plain to the upland region. The bog developed in an elongated granitic bedrock basin of $\sim 240$ ha (of which 160 ha are covered by ombrotrophic peat). At the coring location, the width of the bog area was 800-900 m (Påsse 1989, 1990). The bog surface is located at $23 \mathrm{~m}$ a.s.l. and drainage is to the north-east. The bedrock slope on the eastern side of the basin rises steeply to $140 \mathrm{~m}$ a.s.l. The Spannarp terminal moraine system dams the basin on 
the southern end. Isolation of the basin was dated to 10300 ${ }^{14} \mathrm{C}$ yrs B.P. (Berglund 1995). The Store Mosse Bog was subjected to severe peat cutting, resulting in a system of ditches and ridges across the entire bog surface. Drainage channels were dug around A.D. 1930, allowing for industrial-scale peat cutting. Total peat thickness at the coring point was $332 \mathrm{~cm}$. The peat was underlain by gyttja and marine clays, which were not investigated further. Cores were taken from a remaining ridge in the central northern part of the peatland, where disturbance of the peat sequence was expected to be minimal. Due to the relatively dry conditions, vegetation on these ridges is dense, with a dominance of Ericaceae in the field layer. Birch and pine trees occur frequently, whereas Eriophorum spp. occupies the wet ditches. To the west of the study site, land use is dominated by agriculture, whereas to the east large areas are used for Pinus sylvestris plantations.

The Undarsmosse Bog (ca $120 \mathrm{ha}$ ) is situated $2.5 \mathrm{~km}$ from the present coastline and lies at $20 \mathrm{~m}$ above sea level. It has formed in a shallow granitic basin that is flanked by bedrock hills to the east and west. Drainage occurs to the north-west and there are no inlets. Organic deposits in the central part are ca. $330 \mathrm{~cm}$ thick and lie on top of marine clays. Isolation of the basin was dated to ca. $10250{ }^{14} \mathrm{C}$ yrs B.P. by Berglund (1995). The Undarsmosse Bog is an ombrotrophic bog, with a dominance of Sphagnum spp. in the bottom layer. In the field layer, Calluna and other Ericaceae species are dominant. Low Pinus silvestris and Betula trees occur in small groups. A detailed description and map of the Undarmosse Bog can be found in de Jong et al. (2006). Currently the area around Undarsmosse Bog is used for intensive agriculture, which is typical of this part of the coastal plain.

\section{Upland sites}

The four study sites (Östra Ringarp, Grisavad, Bjärabygget, Värsjö Utmark; Fig. 1) are situated in the upland areas in southern Sweden, near the province border of Halland and Skåne (Lagerås 2007). The area has a hilly topography with altitudes ranging between 80 and $160 \mathrm{~m}$ a.s.l. Bedrock outcrops (gneiss) alternate with sandy till deposits, whereas sandy glaciofluvial deposits dominate the valleys. The area is also rich in peatlands. The most common soils are podsols and brown earth. Present-day land use is dominated by silviculture, which reflects the relatively poor natural conditions for agriculture in the area. Forest cover is approximately $70 \%$, of which the vast majority is coniferous (Picea abies and Pinus sylvestris).

The Östra Ringarp study site is a small fen (ca 1 ha) at $100 \mathrm{~m}$ a.s.l. Coring revealed that the fen is an infilled lake that was finally overgrown ca. 200 yrs ago. At the coring point, organic deposits (mainly gyttja) reached a thickness of $>600 \mathrm{~cm}$, of which the upper $360 \mathrm{~cm}$ were subjected to pollen analysis. A farm with pasture fields lies close to the western edge of the peatland. The surrounding vegetation is entirely dominated by trees (Betula, Pinus and Picea). The Grisavad study site is situated at an altitude of approx. $100 \mathrm{~m}$ above sea level. It is a bog (ca 15 ha) with tree vegetation of Pinus and Betula. The coring point is only $20 \mathrm{~m}$ from the edge, facing the remains of an abandoned croft. Here, total peat thickness was $145 \mathrm{~cm}$. The entire peat sequence was subjected to pollen analysis. Today, the area surrounding the bog is used for silviculture (Picea and Fagus silvatica). The bog site at Bjärabygget sits at an elevation of $120 \mathrm{~m}$ a.s.l. The bog (ca 70 ha) has sparse tree vegetation with scattered dwarf Pinus trees. The bog is large but the coring point for pollen analysis was situated at only $30 \mathrm{~m}$ from the edge. Here, organic deposits reached a thickness of $185 \mathrm{~cm}$, of which the upper $96 \mathrm{~cm}$ were subjected to pollen analysis. The area surrounding the bog is completely forested (Picea and Pinus plantations). The Värsjö Utmark site is situated at $120 \mathrm{~m}$ a.s.l. in an area that is almost completely forested (spruce and pine plantations) except for some small pastures. The site is a small bog ( 2 ha) with sparse spruce and pine vegetation. The core was taken at ca. $20 \mathrm{~m}$ from the edge. Here, organic deposits reached a thickness of $200 \mathrm{~cm}$, of which the upper $65 \mathrm{~cm}$ were subjected to pollen analysis.

\section{Methods and data}

\section{Dating and chronologies}

The chronology for the Store Mosse peat record was based on 10 AMS radiocarbon dates on bulk peat samples (Table I; de Jong et al. 2009). The radiocarbon dates were calibrated using the IntCal04 calibration data set (Reimer et al. 2004) as implemented in the OxCal 3.10 program (Bronk Ramsey 1995, 2001). The upper two radiocarbon dates, which showed anomalously old ages, were excluded from the agedepth model. Recent sediments (younger than ca. 90 cal. yrs в.P.) are therefore missing from the sequence. The chronology for the Undarsmosse core was based on $14{ }^{14} \mathrm{C}$ dates on bulk peat samples (for details, see de Jong et al. 2006).

The chronologies for Östra Ringarp, Grisavad, Bjärabygget and Värsjö Utmark were based on 10, 6, 4 and 6 AMS ${ }^{14} \mathrm{C}$ dates, respectively. Terrestrial plant macrofossils, pollen concentrates and bulk peat samples were used for dating. Detailed information is provided in Lagerås (2007).

\section{Pollen preparation}

Pollen preparation for the Store Mosse bog site was carried out according to standard methods described by Berglund 
and Ralska-Jasiewiczowa (1986) and Moore et al. (1991). Samples were sieved through a $125 \mu \mathrm{m}$ mesh prior to treatment with hydrofluoric acid and acetolysis. Microscope slides were prepared from the residue and pollen, Sphagnum spores and charcoal particles $>25 \mu \mathrm{m}$ were counted. For the 52 samples, a minimum of 500 pollen grains were counted, except at levels with very low pollen concentrations ( $>300$ grains). All taxa were included in the total pollen sum. The pollen keys in Moore et al. (1991) were used for identification, as well as the reference collection at the Department of Quaternary Sciences at Lund University. The percentage diagram was constructed using the TILIA software (Grimm 1992). Prior to zonation, the pollen percentage data were square-root transformed to increase the relative importance of rare species. Zonation of the pollen diagram from the Store Mosse bog was based on optimal sum-of-squares partitioning (Birks and Gordon 1985) as implemented in the program ZONE. The number of statistically meaningful zones was determined by comparison to the broken stick (null) model (Bennett 1996).

\section{Pollen indicating land use}

To compare the agricultural development, pollen types specific to land use were summed for all six study sites (Fig. 3). As indicators of crop cultivation we used Cerealia (Poaceae $>40 \mu \mathrm{m}$ ), Hordeum-type, Triticumtype, Secale and Cannabis/Humulus. At the upland site Östra Ringarp, pollen from Avena, Fagopyrum esculentum and Linum usitatissimum were found in addition to the previous taxa and included in the total 'agricultural indicators' curve. The additional contribution by Cannabis/Humulus was plotted separately since values may be artificially high; it is known that high Cannabis/Humulus values can be caused by the retting of hemp plants in water for fibre production (Bradshaw et al. 1981; Schofield and Waller 2005).

\section{Results}

Store Mosse peat stratigraphy

The peat deposit consisted of fen peat with Carex remains in the bottom part $(332-307 \mathrm{~cm})$, a middle part $(307-193 \mathrm{~cm})$ composed of fen peat with Eriophorum bands and an increasing proportion of Sphagnum remains towards the top, and a top section $(193-33 \mathrm{~cm})$ of Sphagnum peat with a varying degree of decomposition. The top layer $(33-0 \mathrm{~cm})$ represents a re-located layer dated to $\sim 900$ cal. yrs B.P., which was most probably taken out during peat excavation and left on the surface.
Climatic proxies reconstructed at the Store Mosse Bog

The organic bulk density (OBD) reconstruction is shown in Fig. 2. High OBD values indicate strong peat decomposition, reflecting dry local conditions. However, OBD values may also be affected by the plant composition of the peat (see discussion in de Jong et al. 2009). Here, high OBD values coincided with increased total pollen concentrations, supporting the interpretation of OBD as a measure of peat decomposition. As a proxy for bog surface wetness, OBD is most sensitive during ombrotrophic conditions, i.e. when the bog is dependent on the relative amount of precipitation and evapo(transpi)ration directly to and from the bog surface (de Jong et al. 2009). ASI (aeolian sediment influx) values for the Store Mosse and Undarsmosse sites are plotted in Fig. 4. Comparison of both ASI records shows that ASI peak events occurred almost simultaneously at both sites, in particular after ca. 3000 cal. yrs B.P. Detailed climatic interpretations of these ASI records were discussed in de Jong et al. (2006, 2007).

Vegetation development at the Store Mosse bog site

The pollen percentage diagram for the Store Mosse bog is shown in Fig. 2, presenting the 36 most common pollen types. Optimal partitioning resulted in five significant pollen assemblage zones. Total pollen, Sphagnum and charcoal concentrations and OBD values are also shown.

Zone I (to 6400 cal. yrs B.P.)

This zone contains only one sample, which was dominated by Betula, Corylus and Alnus and characterized by extremely high total pollen concentrations.

Interpretation: This zone probably represents the final stage of lake in-filling, with low sediment accumulation rates and hence high pollen, spore and charcoal concentrations. It was not interpreted further.

Zone II (6400-3700 cal. yrs в.P.)

Tree pollen in this zone were dominated by Alnus and Corylus, whereas Betula, Quercus, Pinus and Tilia also reached relatively high values. Ulmus and Tilia reached their maximum values during this time period. Calluna and Poaceae $<40 \mu \mathrm{m}$ dominated the herbs and grasses. Tree taxa constituted $30-50 \%$ of the total pollen percentages, with even higher peaks related to Betula maxima around 5400 cal. yrs B.P. Herb and shrub taxa, in particular $\mathrm{Cal}$ luna and Poaceae, represented 50-70\% of the total pollen sum in the lowermost part of the zone, whereas after ca. 5800 cal. yrs B.P. tree taxa increasingly dominated the vegetation. This period was characterized by high values of 


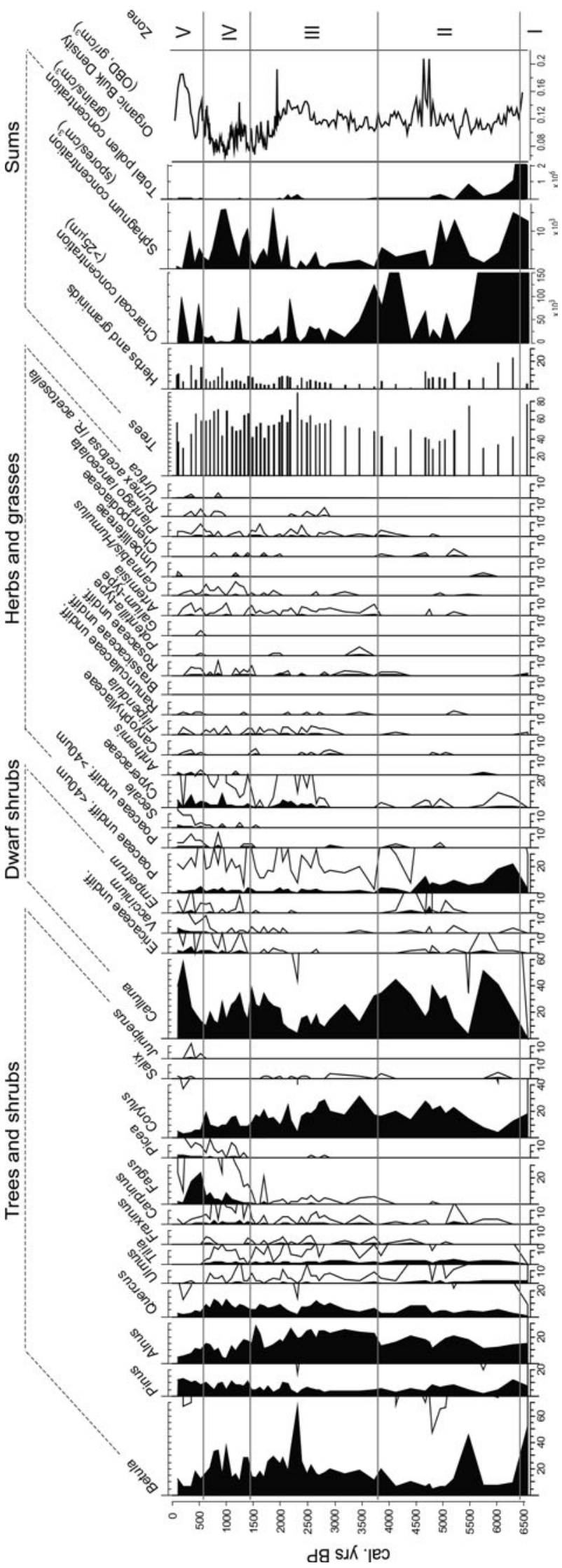

4 Fig. 2 Pollen percentage diagram from the Store Mosse peat bog (percentages plotted against an age scale). The zonation based on optimal sum-of-squares partitioning is shown to the right. Also shown are the concentrations of charcoal particles, Sphagnum spores and total pollen. To the right, ash-free organic bulk density (OBD) values are plotted, a proxy reflecting local to regional-scale variations in bog surface wetness (de Jong et al. 2009). Note the similarity between OBD values and total pollen concentrations, in particular after 2500 cal. yrs в.P.

Betula, Alnus, Corylus and Calluna in particular, and a decrease of Cyperaceae and Poaceae $<40 \mu \mathrm{m}$. In addition, total pollen and charcoal concentrations decreased, whereas Sphagnum concentrations fluctuated strongly.

Interpretation: The high total pollen concentrations and high values for Poaceae $<40 \mu \mathrm{m}$, Calluna and Cyperaceae prior to ca. 5800 cal. yrs B.P. most probably reflect a fen vegetation that was developed by progressive infilling of the lake that existed earlier. After $5800 \mathrm{cal}$. yrs B.P. Sphagnum became an increasingly important peat constituent, as seen in the core stratigraphy. The site was probably a fen, with a mosaic of vegetation types with dry hummocks covered by Calluna and other heath types and wet patches occupied by Sphagnum, Poacaea and Cyperaceae. Scattered finds of Caryophyllaceae, Artemisia, Chenopodiaceae and Plantago lanceolata may indicate human impact in the area after $5500 \mathrm{cal}$. yrs B.P. The sporadic appearance of Carpinus points to small-scale forest disturbances around this time.

\section{Zone III (3700-1450 cal. yrs в.P.)}

The lower zone boundary was characterised by an increase in Betula, Alnus, the regular appearance of Fagus and a decrease in Calluna and Poaceae. Total pollen, charcoal and Sphagnum concentrations decreased markedly. Tree pollen in this zone were dominated by Alnus, Corylus and Betula, whereas Quercus, Tilia, Carpinus and Fagus occurred regularly at low abundances. Total tree pollen values varied around $50-70 \%$, with one peak (85\%) around 2300 cal. yrs B.P., caused by high Betula values. Dominant herb taxa were Calluna and Poaceae $<40 \mu \mathrm{m}$ and in the upper half of the zone also Cyperaceae. Artemisia and $P$. lanceolata occurred regularly at low frequencies. Towards the end of this subzone, Sphagnum spore concentrations and Calluna increased markedly.

Interpretation: The initial decrease of Calluna and Poaceae $<40 \mu \mathrm{m}$ may point to more humid conditions at the study site. The site was most probably still a fen, with a mosaic of relatively wet and dry vegetation patches. Alnus and Betula may have been more common around the margins of the site. The high Betula peak around $2300 \mathrm{cal}$. yrs B.P. coincides with increased total pollen concentrations 
and OBD values. This may indicate the local occurrence of Betula on the bog during a temporary dry spell. After that, the increase in Sphagnum concentrations and rapidly decreasing OBD values indicate the onset of ombrotrophic bog formation. The bog was characterised by hummocks with heath vegetation and hollows with Sphagnum. However, conditions were more humid than before and dry hummock vegetation was less common.

The occurrence of Artemisia, R. acetosa/acetosella, and $P$. lanceolata throughout this zone reflects human impact in the area. This is also indicated by the continuous presence of Fagus, which is known to depend on forest disturbances to establish and expand (Björkman and Bradshaw 1996; Lindbladh et al. 2008). Sporadic finds of Poaceae $>40 \mu \mathrm{m}$ and Secale at the end of this zone point to nearby cereal cultivation.

Zone IV (1450-600 cal. yrs B.P.)

Tree pollen in this zone were characterized by Betula, Pinus, Quercus and Corylus, relatively high values for Carpinus and a steady increase of Fagus and Picea pollen. Tilia and Ulmus pollen occurred at low frequencies. Calluna decreased but still dominated the herb taxa, whereas Cyperaceae increased. Secale and Poaceae $>40 \mu$ m occurred sporadically in this zone. Cannabis/Humulus values were relatively high. Sphagnum concentrations peaked.

Interpretation: The site was an ombrotrophic bog during this time period and bog surface wetness was generally high, as shown by the high Sphagnum spore concentrations, low total pollen concentrations and low organic bulk density values. The increases of Fagus and Picea indicate a further strong disturbance of the surrounding forest, possibly by forest burning; a single charcoal peak was recorded just before the increase in Fagus pollen. Agricultural activity increased during this time period, with rye becoming the most important cereal. Cannabis/Humulus occurred frequently, possibly indicating hemp cultivation.

Zone V (600-90 cal. yrs B.P.)

The pollen assemblages in this zone were initially dominated by Fagus. Picea values increased. All other broadleaved trees decreased and Tilia, Fraxinus and Ulmus (almost) disappeared from the pollen assemblages. Juniperus occurred for the first time. After ca. 200 cal. yrs B.P. the assemblages were entirely dominated by Calluna. Secale and Poaceae $>40 \mu \mathrm{m}$ occurred at relatively high values.

Interpretation: The decrease of Ulmus, Tilia and Carpinus points to severe forest disturbance. This strongly favoured Fagus and Picea. Around ca. 200 cal. yrs B.P. the rapid increase of Calluna reflects the development of widespread heathlands. Even though Calluna heaths were already present much earlier in the coastal region (e.g. Digerfeldt 1982; Thelaus 1989), they became most widespread from 200 to 100 cal. yrs B.P. This expansion has been observed frequently in the coastal areas of southern Scandinavia (e.g. Björkman 2001; Digerfeldt and Håkansson 1993; Lagerås 2007; Malmström 1939), and has been attributed to intense land use on poor soils, where grazing and heath burning resulted in the development of extensive heathlands (Behre 1981). This is supported by the presence of Juniperus, a common species on grazed heath (Berglund 1985), and a peak in charcoal concentrations at this time. This was accompanied by a decrease in Sphagnum and increased OBD values, reflecting dry local conditions.

\section{Discussion}

Patterns of land use variations?

The comparison of land use indicators from the lowland sites (Store Mosse Bog, Undarsmosse Bog) and the four upland sites (Östra Ringarp, Grisavad, Bjärabygget, Värsjö Utmark) is shown in Fig. 3. It should be kept in mind that dating uncertainties vary strongly between sites and over time. More information on the chronological control at the different sites is provided in Table 1 (Store Mosse Bog, de Jong et al. 2009; Undarsmosse Bog, de Jong et al. 2006; all upland sites, Lagerås 2007). In addition, it is important to note that due to the low pollen productivity and dispersal of cereal pollen in particular (e.g. Gaillard et al. 2000; Sugita et al. 1999), the true extent of agricultural land use is greatly underestimated in the pollen percentage values presented in Fig. 3. An additional difficulty in the comparison of vegetation reconstructions from different sites is related to the relevant source area of pollen (RSAP, sensu Sugita 1994). As listed in the site descriptions, the sizes of the upland and lowland peat bogs differ considerably, which affects the RSAP (Sugita 1994). For southern Sweden, in a setting with traditional land use and associated taxa composition, Hellman et al. (2009) found that the RSAP for lake basins with a 25-250 m radius (ca $0.2-2$ ha assuming a circular basin) ranged between 1,200 and $3,000 \mathrm{~m}$. In this study, we compared vegetation reconstructions from sites within this size range (Värsjö Utmark, Östra Ringarp) with data obtained from much larger sites. Moreover, the relevant source area of pollen may vary over time at a given location as demonstrated in Hellman et al. (2009), which they tentatively associated with changes in patch size and spatial distribution of patches. Vegetation patch size and the spatial distribution of patches probably differ between the upland and coastal regions in this study, due to the different topography, geology and hydrology and the resulting suitability for different types of land use in 
Fig. 3 The total percentage of pollen indicating agriculture (Cerealia, Avena, Hordeum, Triticum, Secale, Fagopyrum esculentum and Linum usitassimum (black line) is shown for six sites. Grey lines reflect all pollen indicating agriculture (as listed before) plus Cannabis/Humulus percentages

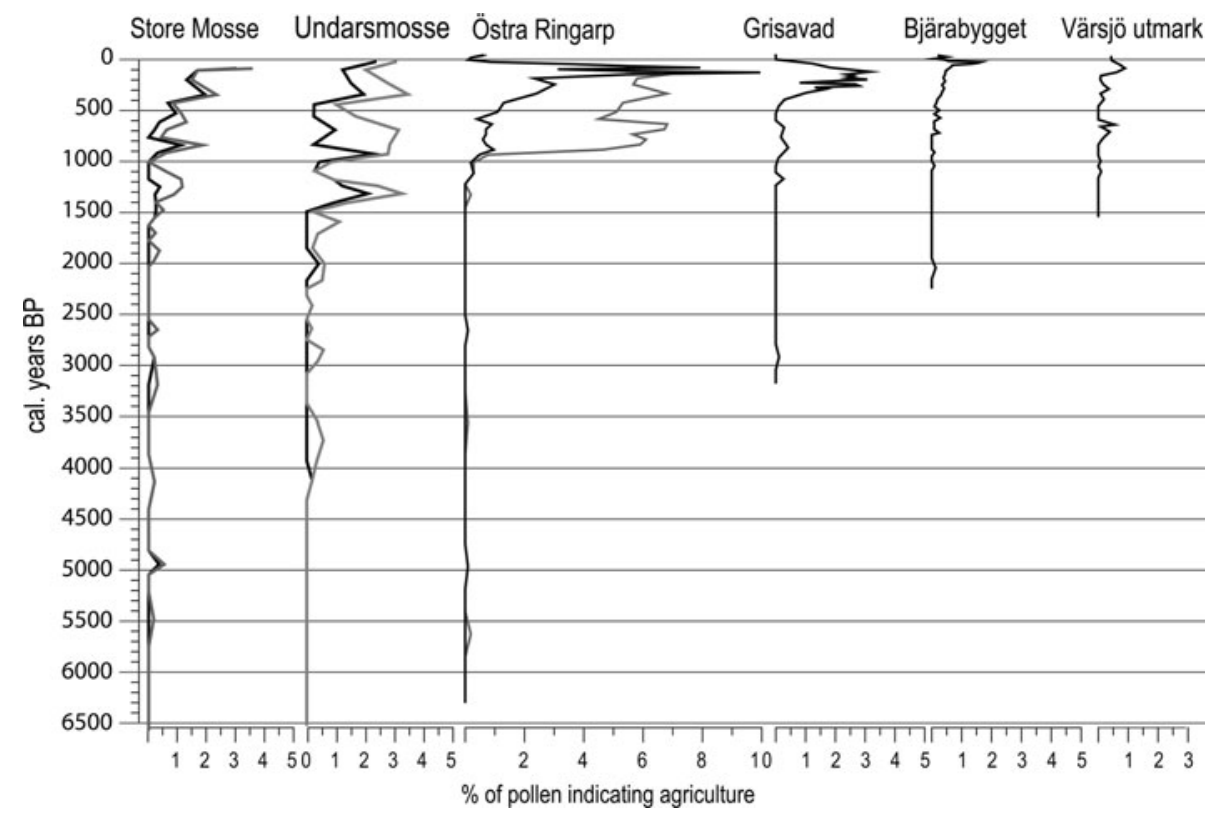

Table 1 AMS ${ }^{14} \mathrm{C}$ ages and calibrated ages for Store Mosse Bog (de Jong et al. 2009)

\begin{tabular}{llrl}
\hline Depth $(\mathrm{cm})$ & Lab. no. & ${ }^{14}$ C age & $\begin{array}{l}\text { Cal. age в.P. } \\
(2 \sigma \text {-range })\end{array}$ \\
\hline $4-5^{\text {a }}$ & LuS 6409 & $990 \pm 50$ & $882 \pm 101$ \\
$26-27^{\text {a }}$ & LuS 6410 & $985 \pm 40$ & $878 \pm 83$ \\
$35-36$ & LuS 6619 & $140 \pm 40$ & $105 \pm 50$ or $225 \pm 60$ \\
$45-46$ & LuS 6449 & $470 \pm 40$ & $507 \pm 46$ \\
$70-71$ & LuS 6411 & $850 \pm 40$ & $743 \pm 60$ \\
$105-106$ & LuS 6412 & $1145 \pm 40$ & $1070 \pm 100$ \\
$142-143$ & LuS 6413 & $1540 \pm 50$ & $1435 \pm 100$ \\
$181-182$ & LuS 6414 & $1905 \pm 40$ & $1830 \pm 100$ \\
$200-201$ & LuS 6620 & $2095 \pm 50$ & $2045 \pm 115$ \\
$223-224$ & LuS 6450 & $2670 \pm 40$ & $2800 \pm 50$ \\
$272-273$ & LuS 6451 & $3850 \pm 50$ & $4280 \pm 135$ \\
$339-340$ & LuS 6452 & $5920 \pm 50$ & $6760 \pm 120$ \\
\hline
\end{tabular}

${ }^{a}$ Dates from the top $30 \mathrm{~cm}$ were excluded from the age-depth model (see text)

each region. In addition, since all study sites included in Fig. 3 are peat bogs, the presence of local vegetation (growing on the bog) has affected the records to an unknown extent. Land use in the form of pasture and grazing on heathlands was not included in this study, since species such as Poaceae $<40 \mu \mathrm{m}$, Ericaceae and Cyperaceae may have grown on the bogs in the past. These factors should be kept in mind when comparing pollen records from different localities, since they indicate that the spatial scale that is reflected by each record differs and may also change over time.

Figure 3 shows a comparison of land use indicator curves for the two lowland and four upland sites. The comparison between the upland and lowland sites shows higher pollen percentages indicating land use in the coastal zone prior to $1000 \mathrm{cal}$. yrs B.P. This probably reflects the favourable conditions for (early) agriculture on the coastal plains of Halland (silty and sandy clays) in comparison to the upland regions with frequent bedrock outcrops and poorer soils. Between 3000 and 2600 cal. yrs B.P., a small presence of agricultural indicators was recorded in Store Mosse bog, Undarsmosse bog, Östra Ringarp and Grisavad, possibly representing an agricultural expansion. This finding is in good agreement with studies showing forest clearances and agricultural expansions in, for example, southern Sweden (from ca 2900 to 2400 cal. yrs B.P.; Berglund et al. 1991), nearby Svartemosse Bog (34502600 cal. yrs B.P., Gustavsson et al. 2009), Denmark (from 3000 to 2500 cal. yrs B.P.; Rasmussen 2005) and northwest Europe in general (Berglund 2003). The pollen record from nearby Lake Sämbosjön (Digerfeldt 1982, $10 \mathrm{~km}$ north of the Store Mosse bog, size $\sim 25$ ha) shows a peak of terrestrial herbs and graminids around $2 \mathrm{~m}$ depth, which corresponds to ca $2700{ }^{14} \mathrm{C}$ yrs B.P. and thus probably represents the same time period. The dating of this phase is complex due to the presence of plateaux in the radiocarbon calibration curve around this time. Detailed records from well-dated (annually laminated) Lake Gosciaz in central Poland show a human impact maximum from 3400 to 2700 cal. yrs B.P. (Berglund 2003). In our reconstructions, this expansion phase was followed by near-disappearance of agricultural indicators from the Store Mosse and Östra Ringarp records, whereas at Undarsmosse values were generally low but fluctuating. The Sämbosjön record also shows two temporary decreases in the total sum of terrestrial herbs and graminids, which fall roughly between 2400 
and $2000{ }^{14} \mathrm{C}$ yrs B.P. At Svartemosse bog (Fig. 1, situated ca $10 \mathrm{~km}$ east from the Store Mosse bog, size $2.5 \mathrm{ha}$ ), Gustavsson et al. (2009) recorded a prolonged reduction of land use indicators in comparison to earlier times from ca. $2600-1400 \mathrm{cal}$. yrs B.P., although they did occur sporadically.

After ca. 2200 cal. yrs B.P., changes in land use occurred around the same time at a number of sites included in this study, possibly reflecting the regional character of these developments. Increases in land use indicators were dated to $1450-1300,1000-900,500-300$, and 200-100 cal. yrs B.P. Declines in activity were recorded primarily at the coastal sites from 2600 to 2200,1200 to 1000 and 700 to 500 cal. yrs в.P. (Fig. 3). The pollen record from a small bog (0.5 ha) near Yttra Berg (Sköld et al. 2010), $25 \mathrm{~km}$ east of Store Mosse bog (Fig. 1), shows several similar features; an expansion phase around $1500 \mathrm{cal}$. yrs B.P., decreased cultural indicators from 1200 to 1000 cal. yrs B.P. and partial abandonment of fields from 650 to $400 \mathrm{cal}$. yrs B.P. At Svartemosse (Gustavsson et al. 2009), cereal pollen peaked initially around $500 \mathrm{cal}$. yrs в.P., followed by a second peak around $100 \mathrm{cal}$. yrs B.P. Three additional pollen records from forest hollows in the Biskopstorp Forest Reserve (Fig. 1, $45 \mathrm{~km}$ to the south-east of Store Mosse Bog) show slightly increasing or relatively high values from 500 to $300 \mathrm{cal}$. yrs B.P. but differ otherwise (Lindbladh et al. 2008). However, it should be kept in mind that several of the records discussed here were derived from small bogs or forest hollows, which primarily record highly localized events. Nevertheless, the above comparisons show that several agricultural expansions were recorded at a number of sites and may therefore reflect regional-scale events, in particular around 3000 to 2600 and 500 to $300 \mathrm{cal}$. yrs в.P.

Climatic variability and agricultural declines at the Store Mosse and Undarsmosse Bog sites

The possible link between climate and agricultural declines was studied by comparing the pollen-based land use reconstructions to climatic reconstructions from the Store Mosse and Undarsmosse bogs. Aeolian sediment influx (ASI) values were compared in detail to the total sums of pollen indicating crop cultivation. Since ASI and pollen analysis were carried out on the same peat cores, there was no chronological offset between these records. Figure 4 shows the total pollen percentages representing crop cultivation from the Store Mosse and Undarsmosse pollen diagrams, together with aeolian sediment influx (ASI) data from the same sites. Also shown are the regional-scale reconstruction of low effective precipitation and decreased bog surface wetness (de Jong et al. 2009), and 'wet-shifts' as recorded in a number of peat bogs in Värmland (central

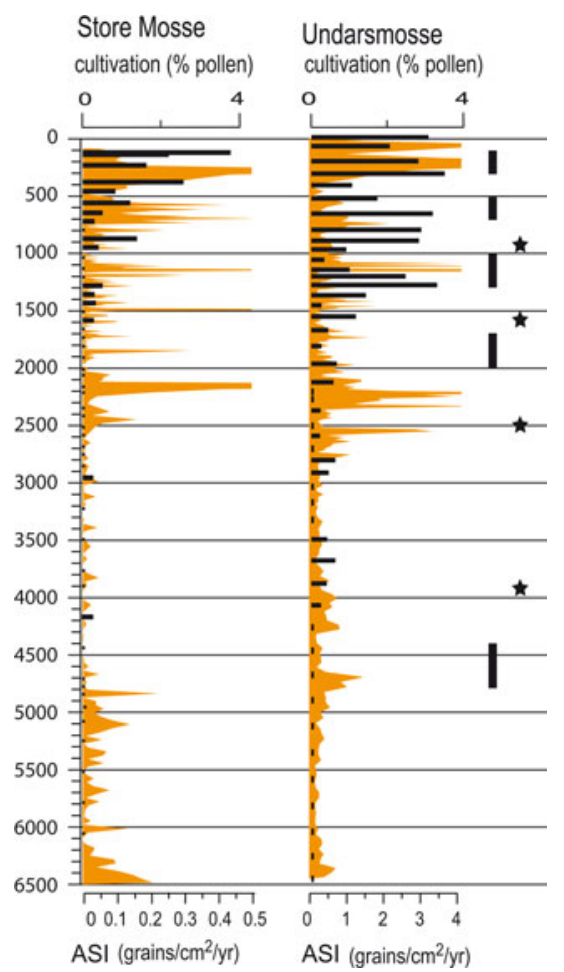

Fig. 4 Comparison of agricultural indicators and climatic reconstructions. Shown are pollen percentages indicating agriculture from the Store Mosse and Undarsmosse Bog sites (all pollen types listed in Fig. 3, including Cannabis/Humulus) compared to aeolian sediment influx (ASI) values from the respective sites. Vertical bars indicate regional-scale phases of low effective precipitation, i.e. relatively dry conditions (de Jong et al. 2009). Also shown are wet-shifts as recorded in peat bogs in Värmland, south-west Sweden (stars: Rundgren 2008)

Sweden) by Rundgren (2008). At the Store Mosse and Undarsmosse study sites, reduced pollen percentages indicating crop cultivation were recorded around 3000 to 2600, 1500, 1200 and between 700 and 500 cal. yrs B.P. (the latter most clearly seen at the Undarsmosse Bog, reduced values at the Store Mosse bog around 500 cal. yrs B.P. only). The possible causes of these declines will now be looked at in detail.

For the time period after 3000 cal. yrs B.P., the relative sequence of events recorded at the Store and Undarsmosse bog sites showed increased agricultural activity from ca. 3000 to $2600 \mathrm{cal}$. yrs B.P., followed by climatic instability (ca. 2600-2200 cal. yrs B.P.; Fig. 4), which coincided with absent or very few pollen types indicating cultivation. The climatic instability at this time was characterised by high ASI values and possibly by increased bog surface wetness around $2500 \mathrm{cal}$. yrs B.P. (Rundgren 2008). The parallel decrease in cultivation and increase in ASI values and bog surface wetness points to a climatic driver for the agricultural decline. These results differ from the interpretation by Berglund (2003), who found a seemingly simultaneous occurrence of climatic changes with increased agricultural 
activities. However, he also stated that 'the chronological precision in the correlations between the climate changes and the settlement/land-use development is still rather weak.' Although dating uncertainties in the Store Mosse and Undarsmosse records were large (up to 150 years), the relative sequence of events recorded at these sites was not affected by chronological uncertainties.

The period around $2700-2400$ cal. yrs B.P. was characterized by a shift to cool and wet conditions in North-West Europe (e.g. Barber et al. 2003, 2004; Speranza et al. 2000; van Geel et al. 1996), although the duration of this wet phase differed spatially. Bakke et al. (2008) showed that the westerly wind belt predominantly affected southern Scandinavia between 2800 and 2400 cal. yrs B.P., as indicated by a strong contrast in winter precipitation on glaciers in the north (low precipitation) and south (high precipitation) of Norway. These findings are generally in good agreement with the climatic instability reconstructed at our two lowland sites. The occurrence of a local-scale agricultural decline may therefore, at least in part, be attributed to a climatic change to conditions unfavourable for agriculture. Increased humidity may have caused crop failures due to parasite attacks (Tinner et al. 2003), whereas an increase of severe storm frequency or storm intensity may have caused more frequent damaging of crop fields. These events would have strongly affected the flat and open coastal zone. The same sequence of events was recorded around 1500 cal. yrs B.P.; the agricultural expansions that started already around $1600 \mathrm{cal}$. yrs B.P. were interrupted at $1500 \mathrm{cal}$. yrs B.P., which coincided with short-lived, high ASI peaks at both sites, and possibly with increased bog surface wetness as reconstructed from a number of sites in north-western Europe (Barber et al. 2003). The timing of this locally short-lived agricultural decline is in good agreement with a number of records from north-west Europe also showing a decline and reforestation at this time (Berglund 2003). Wet conditions accompanied by more frequent or more intense cyclone activity may have contributed to the temporary agricultural decline recorded at this time.

Around $1200 \mathrm{cal}$. yrs B.P. the agricultural expansions at both sites were interrupted, coinciding once more with increased ASI values (Fig. 4). Local bog conditions were dry, whereas both the onset and end of this dry period were marked by clearly wetter bog surface conditions. Studies from peat bogs in the North Atlantic region (e.g. Barber et al. 2003; Hughes et al. 2000) point to a wet-shift occurring at the end of this dry period. It appears that high ASI values from 1200 to 1000 cal. yrs B.P. may be related to atmospheric blocking, causing strong easterly winds and dry conditions (de Jong et al. 2007). Atmospheric blocking over northern Scandinavia is associated with cold and dry winter conditions, since humid and relatively warm oceanic air is diverted to the north or south. It may be that these climatic conditions (more frequent and/or stronger easterlies, cold and dry winters) contributed to the agricultural decline recorded between 1200 and 1000 cal. yrs B.P.

The last phase of agricultural decline was recorded around 700-500 cal. yrs B.P. Lagerås (2007) described this period in detail and showed that at certain sites (Grisavad; Värsjö Utmark) cultivation ceased completely, indicating farm abandonment. A similar agricultural decline was recorded in a number of records from southern Sweden (Berglund et al. 2002; Lagerås 2007; Sköld et al. 2010). Although ASI values at the Store Mosse Bog were high and peak values coincided with the local agricultural decline, this was not the case at Undarsmosse Bog (Fig. 4). Here, ASI values reached peak values during a period of local agricultural expansion (around $800 \mathrm{cal}$. yrs B.P.). Regional scale effective precipitation was low from ca 700-500 cal. yrs в.P. (Fig. 3b), but at the Undarsmosse site bog surface wetness was relatively high (de Jong et al. 2007). It therefore seems that there were no strong climatic forcing factors that may explain the regional-scale agricultural decline recorded at this time. Several authors (Lagerås 2007; Myrdal 2003, 2006; Sköld et al. 2010) have attributed the agricultural decline to the Black Death, which affected large parts of Europe in the 14th century, causing a major population drop. The general population decline in Europe during the late 14 th and early 15 th century has been estimated to have been at least 30\% (Livi Bacci 2000), and in Sweden it has been suggested that population numbers fell by as much as 40-50\% (Myrdal 2006) or even 60-70\% (Palm 2000, 2001). The plague hit both central and marginal areas, but it resulted in long-lasting farm abandonment mainly in forest regions and other areas with relatively poor natural conditions for agriculture (Lagerås 2007).

\section{Agricultural expansions during the 'Little Ice Age'}

An agricultural expansion phase was recorded in all (lowland and upland) pollen diagrams around 500-300 cal. yrs B.P. (Fig. 3a). During this period, particularly in the 16th century, agriculture expanded all over southern Sweden. On the agricultural plains cultivation was intensified and in forested uplands new farms and agricultural land were established. Many farms abandoned during the late-medieval decline were now re-established (Lagerås 2007). This was also a period of technological development, for instance with large-scale iron production, and with a strong development of trade (Myrdal 1999a, b). Climatically, this expansion phase falls into the so-called Little Ice Age, which started before the early 14th century A.D. in regions around the North Atlantic (Grove 2001) and ended near the end of the 19th century. This climatically unstable time period is known for large-scale glacier expansions 
(e.g. Nesje et al. 2007) and cool, fluctuating summer conditions (Grudd et al. 2002; Larocque-Tobler et al. 2009). Figure 4 shows that this period was characterized locally by high ASI values and dry conditions, whereas increased minerogenic influx onto peat bogs were also recorded along the Norwegian coast (Sjögren 2009) and in northern Poland (de Vleeschouwer et al. 2009, an overview of methods used and results is provided in de Jong et al. 2010). However, these high ASI values were in part caused by a strong increase in the finest fraction (de Jong et al. 2006), which suggests that soil erosion caused by intense land use probably amplified the ASI signal during this time.

Despite these well-known climatic changes to conditions that were generally unfavourable for agriculture, an agricultural expansion took place. Obviously, positive factors in society together with the strong population rise after the late medieval crisis outweighed the possible negative effects of climate deterioration. In particular the 16 th century was a period of stronger states, increased division of labour, well-developed markets, far-reaching trade and technical progress (Myrdal 1999a, b; Söderberg and Myrdal 2002). This development enabled economic expansion and population growth in spite of the relatively poor climatic conditions and seems to have drastically diminished society's sensitivity to climatic changes.

\section{Conclusions}

The pollen analytical study of the Store Mosse peat bog enabled the reconstruction of peat bog development and vegetation changes in the coastal zone of Halland. Together with the study carried out at the Undarsmosse Bog, this provided reconstructions of vegetation changes that were compared directly to independent climatic reconstructions obtained from the same peat cores. These data were used to study the possible causal link between climatic variability and agricultural declines. The agricultural declines recorded primarily in the two lowland peat bogs around 2600-2200 cal. yrs B.P., 1500 cal. yrs B.P. and possibly around 1200-1000 cal. yrs B.P. may be attributed to climatic changes that were unfavourable for agriculture, whereas the decline around 700-500 cal. yrs B.P. may have been caused by a strong population drop related to the Black Death. The agricultural expansion during the Little Ice Age, which was characterized regionally by increased cyclone intensity and cool summer conditions, suggests that by this time agriculture and society had become less sensitive to climatic forcing.

Acknowledgments We are grateful to L. Björkman for offering his expert knowledge on pollen analysis and discussions on vegetation and land use reconstructions. We would also like to thank Marie-Jose
Gaillard for valuable comments and suggestions. We gratefully acknowledge the comments and suggestions from two reviewers, A.B. Nielsen and M. Lindbladh. AMS ${ }^{14} \mathrm{C}$ dating was carried out at the Radiocarbon Dating Laboratory in Lund, Sweden. Dating was supported by the Royal Physiographic Society (Lund).

\section{References}

Alexandersson H, Schmith T, Iden K, Tuomenvirta H (1998) Longterm variations of the storm climate over NW Europe. Global Atmos Ocean Syst 6:97-120

Bakke J, Lie Ø, Dahl SO, Nesje A, Bjune AE (2008) Strength and spatial patterns of the Holocene wintertime westerlies in the NE Atlantic region. Global Planet Change 60:28-41

Barber KE, Chambers FM, Maddy D (2003) Holocene palaeoclimates from peat stratigraphy: macrofossil proxy climate records from three oceanic raised bogs in England and Ireland. Quat Sci Rev 22:521-539

Barber K, Chambers FM, Maddy D (2004) Late Holocene climatic history of northern Germany and Denmark: peat fossil investigations at Dosenmoor, Schleswig-Holstein, and Svanemose, Jutland. Boreas 33:132-144

Behre K-E (1981) The interpretation of anthropogenic indicators in pollen diagrams. Pollen Spores 23:225-245

Bennett KD (1996) Determination of the number of zones in a biostratigraphical sequence. New Phytol 132:155-170

Berglund BE (1985) Early agriculture in Scandinavia: research problems related to pollen-analytical studies. Norwegian Archaeol Rev 18:77-105

Berglund M (1995) The late Weichselian deglaciation, vegetational development and shoreline displacement in Halland, southwestern Sweden. Dissertation, Lund University

Berglund BE (2003) Human impact and climate changes-synchronous events and a causal link? Quat Int 105:7-12

Berglund BE, Ralska-Jasiewiczowa M (1986) Pollen analysis and pollen diagrams. In: Berglund BE (ed) Handbook of Holocene palaeoecology and palaeohydrology. Wiley, Chichester, pp 455-484

Berglund BE, Malmer N, Persson T (1991) Landscape-ecological aspects of long-term changes in the Ystad area. In: Berglund BE (ed) The cultural landscape during 6,000 years in southern Sweden-the Ystad project. Ecol Bull 41, pp 405-424

Berglund BE, Lagerås P, Regnéll J (2002) Odlingslandskapets historia i Sydsverige: en pollenanalytisk syntes. In: Berglund BE, Börjesson $\mathrm{K}$ (eds) Markens minnen: landskap och odlingshistoria på Småländska höglandet under 6000 år. Riksantikvarieämbetet, Stockholm, pp 153-174

Birks HJB, Gordon AD (1985) Numerical methods in quaternary pollen analysis. Academic Press, London

Björck S, Clemmensen LB (2004) Aeolian sediment in raised bog deposits, Halland, SW Sweden: a new proxy record of Holocene winter storminess variation in southern Scandinavia? Holocene 14:677-688

Björkman L (2001) The role of human disturbance in Late Holocene vegetation changes on Kullaberg, southern Sweden. Veget Hist Archaeobot 10:201-210

Björkman L, Bradshaw R (1996) The immigration of Fagus sylvatica L. and Picea abies (L.) Karst. into a natural forest stand in southern Sweden during the last 2,000 years. J Biogeogr 23:235-244

Bradshaw RHW, Coxon P, Greig JRA, Hall AR (1981) New fossil evidence of the past cultivation and processing of hemp (Cannabis sativa L.) in eastern England. New Phytol 89:503-510 
Bronk Ramsey C (1995) Radiocarbon calibration and analysis of stratigraphy: the OxCal program. Radiocarbon 37:425-430

Bronk Ramsey C (2001) Development of the radiocarbon calibration program. Radiocarbon 43:355-363

de Jong R, Björck S, Björkman L, Clemmensen LB (2006) Storminess variation during the last 6,500 years as reconstructed from an ombrotrophic peat bog in Halland, SW Sweden. J Quat Sci 21:905-919

de Jong R, Schoning K, Björck S (2007) Increased aeolian activity during humidity shifts as recorded in a raised bog in south-west Sweden during the past 1,700 years. Clim Past 3:411-422

de Jong R, Hammarlund D, Nesje A (2009) Late Holocene effective precipitation variations in the maritime regions of south-west Scandinavia. Quat Sci Rev 28:54-64

de Jong R, Blaauw M, Chambers FM, Christensen TR, de Vleeschouwer F, Finsinger W, Fronzek S, Johansson M, Kokfelt U, Lamentowicz M, Le Roux G, Mauquoy D, Mitchell EAD, Nichols JE, Samaritani E, van Geel B (2010) Climate and peatlands. In: Dodson J (ed) Changing climates, earth systems and society. Springer, Dordrecht, pp 85-121

De Vleeschouwer F, Cheburkin A, Le Roux G, Piotrowska N, Sikorski J, Lamentowicz M, Fagel N, Mauquoy M (2009) Multiproxy evidences of Little Ice Age palaeoenvironmental changes in a peat bog from northern Poland. Holocene $19: 625-637$

Digerfeldt G (1982) The Holocene development of lake Sämbosjön 1. The regional vegetation history. LUNDQUA report 23, Lund University

Digerfeldt G, Håkansson H (1993) The Holocene paleolimnology of lake Sämbosjön, Southwestern Sweden. J Paleolimnol 8:189-210

Digerfeldt G, Welinder S (1985) An example of the establishment of the Bronze Age cultural landscape in SW Scandinavia. Norwegian Archaeol Rev 18:106-114

Gaillard M-J, Sugita S, Broström A, Eklöf M, Pilesjö P (2000) Long term land cover changes on regional to global scales inferred from fossil pollen-how to meet the challenges of climate research? Pages Newsletter 8:30-32

Gajewski K, Viau AE, Sawada M, Atkinson DE, Fines P (2006) Synchronicity in climate and vegetation transitions between Europe and North America during the Holocene. Clim Change 78:341-361

Grimm EC (1992) Tilia and Tilia graph: pollen spreadsheets and graphics programs. Programs and Abstracts, 8th International Palynological Congress, Aix-en-Provence, September 6-12, 1992

Grove JM (2001) The initiation of the 'Little Ice Age' in regions round the North Atlantic. Clim Change 48:53-82

Grudd H, Briffa K, Karlén W, Bartholin TS, Jones PD, Kromer B (2002) A 7400-year tree ring chronology in northern Swedish Lapland: natural climatic variability expressed on annual to millennial timescales. Holocene 12:657-665

Gustavsson G, Lemdahl G, Gaillard M-J (2009) Abrupt forest ecosystem change in SW Sweden during the late Holocene. Holocene 19:691-702

Hellman S, Gaillard M-J, Bunting JM, Mazier F (2009) Estimating the Relevant Source Area of Pollen in the past cultural landscapes of southern Sweden-a forward modelling approach. Rev Palaeobot Palynol 153:259-271

Hughes PDM, Mauquoy D, Barber KE, Langdon PG (2000) Miredevelopment pathways and palaeoclimatic records from a full Holocene peat archive at Walton Mosse, Cumbria, England. Holocene 10:467-479

Jönsson P (1994) Wind climate during the instrumental period and recent wind erosion in Southern Scandinavia. Meddelanden från Lund Universitet Geografiska Institutioner, avhandlingar 121
Jönsson P, Bärring L (1994) Zonal index variations, 1899-1992: links to air temperature in southern Scandinavia. Geografiska Annaler Serie A-Physical Geography 76:207-219

Lagerås $P$ (2007) The ecology of expansion and abandonment: medieval and post-medieval agriculture and settlement in a landscape perspective. Riksantikvarieämbetet, Stockholm

Larocque-Tobler I, Grosjean M, Heiri O, Trachsel M (2009) Highresolution chironomid-inferred temperature history since A.D. 1580 from varved Lake Silvaplana, Switzerland: comparison with local and regional reconstructions. Holocene 19:1,201-1,212

Lindbladh M, Niklasson M, Karlsson M, Björkman L, Churski M (2008) Close anthropogenic control of Fagus sylvatica establishment and expansion in a Swedish protected landscapeimplications for forest history and conservation. J Biogeogr 35:682-697

Livi Bacci M (2000) The population of Europe: a history. Blackwell, Oxford

Lundqvist J, Wohlfarth B (2001) Timing and east-west correlation ofsouth Swedish ice marginal lines during the late Weichselian. Quat Sci Rev 20:1,127-1,148

Malmström C (1939) Hallands skogar under de senaste 300 åren. En översikt över deras utbredning och sammansättning enligt officiella dokuments vittnesbörd. Meddelande från Statens Skogsförsöksanstalt 31:171-278

Messerli B, Grosjean M, Hofer T, Nunez L, Pfister C (2000) From nature-dominated to human-dominated environmental changes. Quat Sci Rev 19:459-479

Moore PD, Webb JA, Collinson ME (1991) Pollen analysis. Blackwell, Oxford

Myrdal J (1999a) Jordbruket under feodalismen 1000-1700. Det svenska jordbrukets historia. Natur och Kultur/LT, Stockholm

Myrdal J (1999b) The agrarian revolution restrained: Swedish agrarian technology in the 16th century in a European perspective. In: Liljewall B (ed) Agrarian systems in early Modern Europe: technology, tools, trade. Skrifter om Skogs- och Lantbrukshistoria. Nordiska Museet, Stockholm, pp 96-145

Myrdal J (2003) Digerdöden, pestvågor och ödeläggelse: ett perspektiv på senmedeltidens Sverige. Runica et Mediævalia, Stockholm

Myrdal J (2006) The forgotten plague: the Black Death in Sweden. In: Hämäläinen P (ed) When disease makes history: epidemics and great historical turning points. Helsinki University Press, Helsinki, pp 141-186

Nesje A, Dahl SO, Thun T, Nordli $\varnothing$ (2007) The 'Little Ice Age' glacial expansion in western Scandinavia: summer temperature or winter precipitation? Clim Dynam 30:789-801

Nilsson C, Stjernquist I, Bärring L, Schlyter P, Jönsson AM, Samuelsson H (2004) Recorded storm damage in Swedish forests 1901-2000. Forest Ecol Manag 199:165-173

Palm LA (2000) Folkmängder i Sveriges socknar och kommuner 1571-1997. Nykopia tryck AB, Stockholm

Palm LA (2001) Livet, kärleken och döden. Nykopia Global print AB, Solna, Sweden

Påsse T (1989) Jordartskartan 5b Varberg NO, Sveriges Geologiska Undersökning serie Ae nr 102, Uppsala

Påsse T (1990) Beskrivning till jordartskartan Varberg NO. Sveriges Geologiska Undersökning, serie Ae 102, Uppsala

Rasmussen P (2005) Mid-to late-Holocene land-use change and lake development at Dallund S $\varnothing$, Denmark: vegetation and land-use history inferred from pollen data. Holocene 15:1,116-1,129

Reimer PJ, Baillie MGL, Bard E, Bayliss A, Beck JW, Bertrand C, Blackwell PG, Buck CE, Burr G, Cutler KB, Damon PE, Edwards RL, Fairbanks RG, Friedrich M, Guilderson TP, Hughen KA, Kromer B, McCormac FG, Manning S, Bronk Ramsey C, Reimer RW, Remmele S, Southon JR, Stuiver M, Talamo S, Taylor FW, van der Plicht J, Weyhenmeyer CE 
(2004) IntCal04 Terrestrial Radiocarbon Age Calibration, 0-26 cal Kyr B.P. Radiocarbon 46:1,029-1,058

Rundgren M (2008) Stratigraphy of peatlands in central and northern Sweden: evidence of Holocene climatic change and peat accumulation. GFF 130:95-107

Schofield JE, Waller MP (2005) A pollen analytical record for hemp retting from Dungeness Foreland, UK. J Archaeol Sci 32:715-726

Sjögren P (2009) Sand mass accumulation rate as a proxy for wind regimes in the SW Barents Sea during the past $3 \mathrm{ka}$. Holocene 19:591-598

Sjörs H (1965) Forest regions. Acta Phytogeogr Suecica 50:48-63

Sköld E, Lagerås P, Berglund BE (2010) Temporal cultural landscape dynamics in a marginal upland area: agricultural expansions and regressions inferred from palynological evidence at Yttra Berg, southern Sweden. Veget Hist Archaeobot 19:121-136

SMHI (2010) www.smhi.se/klimatdata/meteorologi. Accessed 1 May 2010

Söderberg J, Myrdal J (2002) The agrarian economy of sixteenthcentury Sweden. Acta Universitatis Stockholmiensis. Stockholm Studies in Economic History 35. Almqvist \& Wiksell, Stockholm
Speranza A, van der Plicht J, van Geel B (2000) Improving the time control of the Subboreal/Subatlantic transition in a Czech peat sequence by ${ }^{14} \mathrm{C}$ wiggle-matching. Quat Sci Rev 19:1,589-1,604

Sugita S (1994) Pollen representation of vegetation in Quaternary sediments: theory and method in patchy vegetation. J Ecol 82:881-897

Sugita S, Gaillard M-J, Broström A (1999) Landscape openness and pollen records: a simulation approach. Holocene 9:409-421

Thelaus M (1989) Late Quaternary vegetation history and palaeohydrology of the Sandsjön-Årshult area, southwestern Sweden. Dissertation, Lund University

Tinner W, Lotter AF, Ammann B, Conedera M, Hubschmid P, van Leeuwen JFN, Wehrli M (2003) Climatic change and contemporaneous land-use phases north and south of the Alps 2300 B.C. to 800 A.D. Quat Sci Rev 22:1,447-1,460

Van Geel B, Buurman J, Waterbolk HT (1996) Archaeological and palaeoecological indications of an abrupt climate change in The Netherlands, and evidence for climatological teleconnections around 2650 B.P. J Quat Sci 11:451-460 